\title{
PERAN KONTEKS DALAM PENENTUAN MAKNA TERSIRAT TEKS: KASUS TIGA TEKS FORENSIK BAHASA INDONESIA ${ }^{1}$
}

\author{
I Wayan Pastika \\ Universitas Udayana \\ Posel: wayanpastika@unud.ac.id \\ Artikel dikirim: 12 Juli 2021 Diterima: 21 Agustus 2021

\section{THE ROLE OF CONTEXT IN IMPLIED MEANING DETERMINATION: CASE OF THREE INDONESIAN FORENSIC TEXTS}

\begin{abstract}
Freedom of expression in Indonesia has reached the best momentum after the reformation era for democracy develops very successfully to the right direction in the last two decades. One such freedoms is free media and this progressive opportunity often been manipulated by particular users. Thanks to the Indonesian government that has issued constitutional law to punish wrong doing of irresponsible users on electronic transation of information i.e UU ITE Number 11 year 2018 and UU ITE Number 19 year 2016. In this paper there are two research questions to investigate: (1) What linguistics strategy is applied to determine implied meaning of a text; (2) How socio-pragmatic contexts and intertexts play a significant role in analyzing the message. The objective of the research is to formulate a Forensic Linguistics perspective on determining implied meaning and message. The result is that implied meaning must be searched by employing lexico-grammatical structures and supported by socio-pragmatic contexts, namely, deictic, implicature and speech acts. It is concluded that in investigating forensic texts particularly to find out deep structure of meaning and messages behind the surface text, microlinguistics and macrolinguistics properties should be imposed in order to formulate language crime supported by linguistic evidences.
\end{abstract}

Keywords: forensic linguistics; meaning; message; texts

\section{PENDAHULUAN}

Kepolisian Republik Indonesia (Polri) mencatat 2700 laporan dari seluruh Indonesia berkaitan dengan pelanggaran Undang-Undang Informasi dan Transaksi Elektronik (UU ITE 2008) selama 2016. Semua pelanggaran itu berkaitan dengan pasal 27: fitnah, penghinaan dan ujaran kebencian; pasal 28 tentang kebencian Suku Agama

\footnotetext{
${ }^{1}$ Artikel ini pernah disajikan pada Simposium ke-49 Himpunan Peneliti Indonesia Seluruh Jepang, 17 - 18 November 2018, di Nanzan University, Nagoya, Jepang; tetapi belum pernah dipublikasikan. Pada awal Juli 2021 dilakukan revisi untuk publikasi artikel jurnal STILISTIKA, yang terbit perdana tahun 2021.
} 


\section{STILISTIKA}

Journal of Indonesian Language and Literature

Vol.01, No.01: Oktober 2021, pp-82- 103.

Ras dan Antargolongan (SARA) dan pasal 29 tentang informasi disertai ancaman. Separuhnya sudah dituntaskan oleh Polri, sementara sisanya belum bisa diselesaikan. (Berita Nasional, m.viv.co.id 6 Januari 2017)

Dugaan pelanggaran seperti yang diatur dalam pasal 27 dan 28 tersebut di atas dapat ditemukan pada ketiga teks forensik yang dibicarakan di sini. Namun demikian, alasan tiga (bagian) teks yang berkasus hukum dibahas di sini lebih banyak ditentukan oleh pemikiran bahwa ketiganya mewakili jati diri masing-masing kelompok yang besar yaitu masyarakat agama dan budaya. Teks pertama adalah bagian teks yang diucapkan oleh B.T.P alias Ak:2 “...dibohongin pake Surat Al-Maidah Ayat 51....". Teks ini mengusik jati diri umat Islam di Indonesia sehingga menjadi kontroversi nasional. Teks yang kedua adalah teks pernyataan yang diucapkan oleh E.S, antara lain: "Tidak ada ajaran selain Islam. Ingat, ya, digarisbawahi selain Islam yang sesuai dengan Pancasila. Selain Islam (.) bertentangan (.) karena Kristen (.) Trinitas, Hindu (.) Tri Murti, Budha, sepengetahuan saya tidak punya konsep Tuhan...". Teks ini dianggap merendahkan ajaran agama: Kristen, Hindhu, dan Budha dan tentunya juga merendahkan pemeluknya. Teks yang terakhir adalah teks yang berkaitan dengan ketersinggungan budaya antara tokoh masyarakat dan seorang gubernur.

Dua teks pertama dikumpulkan melalui media sosial Youtube yang diamati secara khusus setelah dijadikan materi teks forensik. Sementara itu, teks tertulis dikumpulkan dari pihak yang terlibat perkara (pengacara/terlapor). Teks lisan dari Youtube didengarkan secara berulang-ulang dan ditranskripsikan serta dicermati, sementara teks tulis hanya dibaca dan dicermati sebelum menjadi data. Setelah itu, masing-masing teks disegmentasi untuk mengetahui dan memahami bagian teks yang

\footnotetext{
2 Dia menjabat Gubernur DKI Jakarta sejak 19 November 2014 hingga 9 Mei 2017. Dalam Pemilihan Umum Gubernur DKI Jakarta periode 2017 - 2022 dia kalah. Kekalahannya itu sering dikaitkan oleh sebagian masyarakat ada hubungannya dengan protes umat Islam berkaitan dengan ucapannya yang dianggap menghina agama Islam.
} 


\section{STILISTIKA}

Journal of Indonesian Language and Literature

Vol.01, No.01: Oktober 2021, pp-82- 103.

menjadi inti permasalahan hukum sebelum ditetapkan sebagai data. Akhirnya, analisis data dilakukan dengan mempertimbangkan konteks bahasa dan konteks di luar bahasa.

Pemanfaatan sumber informasi elektronik seperti Youtube dibolehkan oleh UU ITE 2008 untuk kepentingan penelitian, seperti disebutkan dalam Pasal 34 Ayat 2 sebagai berikut.

“Tindakan sebagaimana dimaksud pada ayat (1) bukan tindak pidana jika ditujukan untuk melakukan kegiatan penelitian, pengujian Sistem Elektronik, untuk perlindungan Sistem Elektronik itu sendiri secara sah dan tidak melawan hukum."

Masalah pokok yang dibahas dalam makalah ini adalah (1) strategi apakah yang dapat ditetapkan untuk menentukan makna tersirat suatu teks dan (2) bagaimanakah peran kon-teks sosio-pragmatik dan ko-teks dalam mempengaruhi makna suatu teks. Dalam kaitan dengan kedua masalah pokok itu, ditetapkan dua tujuan: (1) memastikan ketegasan makna berdasarkan dukungan bukti linguistik dan (2) menjelaskan keterkaitan kon-teks dan ko-teks dalam mendukung makna teks. Luaran (output) dari studi kecil ini adalah suatu bentuk analisis teks forensik yang bertumpu pada buktibukti linguistik. Di samping itu, hasil (outcome) yang diharapkan adalah keinginan membantu masyarakat agar lebih objektif mempertimbangkan pesan teks sehingga mereka dapat secara adil memperlakukan pemilik teks.

\section{KAJIAN PUSTAKA}

Tiga penelitian sebelumnya yang bertopik Linguistik Forensik dan kajian teoretis menyangkut mikrolinguistik dan makrolinguistik dikaji dalam bagian ini. Ketiga tulisan tersebut perlu dikaji untuk menunjukkan aspek-aspek linguistik forensik yang telah dilakukan dan aspek-aspek lain yang belum dikerjakan. Artikel ini dimaksudkan untuk mengembangkan persoalan penelitian yang belum dibahas pada ketiga tulisan tersebut dan mengajukan parameter Linguistik Forensik dari persfektif yang lain. 


\section{STILISTIKA}

Journal of Indonesian Language and Literature

Vol.01, No.01: Oktober 2021, pp-82- 103.

Setelah ketiga penelitian sebelumnya dikaji, acuan teoretis dijelaskan, khususnya berkaitan dengan teori mikrolinguistik dan makrolinguistik yang dianggap dapat mendukung pendekatan Linguistik Forensik.

Dalam makalah yang ditulis oleh Pastika (2018) berjudul "Kekerasan Verbal dalam Teks Forensik Bahasa Indonesia" dinyatakan bahwa teks yang dihasilkan oleh pengujar atau penulis dapat dianggap sebagai suatu ancaman kalau menimbulkan rasa tidak aman bagi pihak yang disasar. Peristiwa semacam itu dapat diajukan sebagai kasus hukum agar pihak yang menjadi korban mendapakan keadilan. Tidak hanya dibahas penggunaan bahasa kasar dan ancaman, tetapi juga bentuk-bentuk metaforis yang mengandung perendahan, penggolongan negatif, pemaparan hubungan seks, dan ancaman peringatan. Dalam penegakan hukum, bukti-bukti linguistik diperlukan untuk membuktikan adanya bentuk dan makna bahasa yang mengandung kekerasan verbal. Penelitian tersebut berkontribusi dalam analisis struktur teks yang menyangkut stilistika teks ancaman dalam artikel ini, tetapi analisisnya dikembangkan lebih jauh dengan melibatkan analisis konteks luar teks: konteks deiktik, konteks tindak tutur, dan konteks implikatur.

Selanjutnya, dalam artikel yang bertajuk "Pencemaran Nama Baik: Kajian Linguistik Forensik" ditulis oleh Mintowati (2016) dijelaskan bahwa analisis gramatikal berperan dalam penentuan makna kata. Makna itu dapat dipengaruhi oleh konteks kalimat dan konteks wacana untuk menemukan makna penghinaan ataupun pencemaran nama baik. Sementara itu, dari analisis pragmatik, ditemukan bahwa tindak tutur ilokusi ekspresif dan direktif-provokatif terjadi pada teks yang menimbulkan permasalahan hukum. Penelitian tersebut berkontribusi pada artikel ini terutama pemanfaatan analisis gramatikal yang ditunjang oleh konteks wacana untuk menentukan makna penghinaan, tetapi konteks deiktik dan konteks implikatur tidak dibicarakan dalam artikel Mintowati tersebut. 


\section{STILISTIKA}

Journal of Indonesian Language and Literature

Vol.01, No.01: Oktober 2021, pp-82- 103.

Kajian ketiga dalam artikel ini adalah sebuah tulisan bertajuk "Studi Kasus Linguistik Forensik: Hoaks Rekaman Suara yang Diduga Gatot Nurmantyo" yang ditulis oleh Ghozali Saputro (2019). Dalam analisisnya ditemukan bahwa ada perbedaan yang jelas pada teks rekaman Pembicara I (SSM) dengan teks rekaman Pembicara II (SSM) dilihat dari pendekatan Sosiolinguistik, Wacana dan Stilistika. Bukti-bukti linguistik dalam bentuk fonetik dan leksikal ditunjukkan untuk mendukung temuannya, misalnya, adanya pengaruh bahasa daerah: Betawi dan Jawa dalam teks rekaman. Dari segi Linguistik Forensik yang ditunjang dengan metode Skala Kemungkinan Klasik penulisnya berhipotesis bahwa rekaman SSM dan SSA tidak berasal dari penutur yang sama. Letak perbedaan penelitian tersebut dengan artikel ini terdapat pada pilihan pendalamannya. Dalam penelitian Sauptro, lebih ditekankan pembuktian bentu-bentuk linguistiknya, sementara dalam penelitian ini didalami aspek lexico-gramatika yang ditunjang oleh konteks luar teks untuk menemukan makna dan pesan teks.

Teori linguistik dimanfaatkan untuk menjelaskan makna tersirat atau pesan teks yang ditentukan oleh parameter mikrolinguistik dan makrolinguistik, khususnya konteks luar teks. Pendekatan ini berbeda dengan pendekatan semantik yang berfokus pada makna tersurat, yang berarti bahwa makna ditentukan oleh rangkaian leksikogramatika tanpa pertimbangan konteks luar teks. Konteks dalam hal ini adalah konteks deiktik (Grundy, 2000: 22-47); konteks tindak tutur Searle dan konteks implikatur Grice (dalam Sadock, 2004: 53-73).

Konteks deiktik berkaitan dengan makna tersirat dari leksikon: deiktik orang (misalnya acuan dari saya, kamu, dia), deiktik tempat (misalnya, acuan dari di sini, di situ, di sana), dan deiktik waktu (acuan dari nomina atau adverbial waktu: malam ini/itu, kemarin, besok, hari ini, minggu, bulan, tahun, sekarang, sebelumnya, setelahnya). Makna tersirat pronominal saya, kamu, dia dapat dipahami apabila keterlibatan partisipan dapat diketahui, misalnya, saya dalam suatu teks percakapan berarti si pembicara, sementara 


\section{STILISTIKA}

Journal of Indonesian Language and Literature

Vol.01, No.01: Oktober 2021, pp-82- 103.

kamu berarti mitra bicara. Begitu juga dalam halnya deiktik tempat. Ketika di dalam teks digunakan di tempat ini (misalnya, A dan B sedang berada di Jogyakarta, lalu A berkata: "Saya sudah lama tidak berkunjung di tempat ini"), frase di tempat ini berarti 'Jogyakarta' sebagai tempat pembicaraan yang sedang berlangsung. Sedangkan, dalam konteks lain frase di tempat ini berarti tempat berbeda (misalnya, A dan B sedang berkunjung ke Kuta Bali setelah tahun 2002, kemudian A berkata: "Bom besar pernah diledakkan di tempat ini oleh teroris). Frase di tempat ini berarti suatu wilayah yang bernama Kuta di daerah Bali, tempat pembicaraan itu berlangsung. Sementara itu, deiktik waktu berkaitan dengan nomina atau adverbial waktu, misalnya, ketika A dan B sedang berbicara pada hari Minggu, dan berkata: "Kemarin ayah pergi ke Jakarta." Ini berarti makna tersirat dari kemarin adalah 'hari Sabtu' sebelumnya. Tetapi, kemarin bisa berarti ‘hari Jumat' kalau pembicaraan itu berlangsung hari Sabtu.

Konteks tindak tutur berkaitan dengan enam kategori: (1) memberi informasi (assertive): "Ada polisi di sana;" (2) meminta atau menyuruh (directives): "Bisa dikecilkan suara TV-nya?;" (3) menjanjikan (commissives): "Saya berjanji akan melunasinya segera;" (4) mengungkapkan perasaan (expressives): "Terima kasih telah sabar menunggu;" (5) membuat pernyataan (declaratives): "Bulan ini sudah mulai musim hujan;" dan (6) melarang (prohibitives): "Dilarang membuang sampah di sini."

Konteks implikatur sangat membantu penentuan makna tersirat atau makna pragmatik dari teks yang digunakan. Misalnya, ketika A dan B berbicara tentang C yang tamatan Universitas Indonesia (UI) yang mampu membawa kemajuan kepemimpinan suatu lembaga, dan A berkata: "Dia tamatan UI, Iho." Implikatur dari teks tersebut adalah 'pantaslah dia berhasil karena dia seorang sarjana dari salah satu universitas terbaik di Indonesia.' Akan tetapi, ketika $C$ gagal dalam kepemimpinan tersebut dan A menggunakan kalimat yang sama: "Dia tamatan UI, lho." Implikaturnya adalah 'tamatan salah satu universitas terbaik (UI) di Indonesia ternyata biasa-biasa saja.' 
Selain konteks di atas, tingkat ketepatan makna tersirat sebuah teks ditentukan pula oleh laras bahasa (register) dan hubungan interteks. Register merupakan variasi penggunaan bahasa yang ditentukan oleh situasi dan partisipan yang terlibat, sementara itu hubungan interteks diartikan sebagai teks terkait yang bervariasi dari segi pesan dan penggunaan bahasa. Dalam kaitannya dengan register, soal situasi dan partisipan dalam pandangan Halliday \& Hasan (1985: 12) dapat dibedakan atas tiga 'konteks situasi:' (1) latar (field) berkaitan dengan latar sosial terjadinya interkasi; (2) tenor berkaitan dengan hubungan sosial antarpartisipan yang terlibat; dan (3) mode merupakan media komunikasi yang digunakan: saluran komunikasi (lisan, tulisan, monolog, dialog, dsb.) dan modus retorika (persuasif, didaktik, deklaratif, dsb.).

Semua komponen mikrolinguistik dan makrolinguistik di atas sangat menentukan arah kajian linguistik forensik dalam makalah ini. Secara teoretis, pengertian linguistik forensik di sini mengacu konsep yang dikemukakan oleh Olsson dan Luchjenbroers (2014: 157) yang mengatakan bahwa 'sebuah teks forensik menyangkut segala sesuatu yang dikatakan atau ditulis dapat dijadikan bukti penting dalam suatu penyelidikan kasus pidana atau perdata. Semua ini termasuk siapa penutur atau penulis teks, apa makna atau pesan dari teks itu, bahasa yang digunakan dalam tindak kejahatan atau bahasa yang digunakan dalam sidang pengadilan (saksi, pernyataan dari mereka yang berperkara) atau teks dari suatu statuta.'

Tiga teks yang dijadikan korpus penelitian adalah teks yang menyita perhatian masyarakat baik di tingkat nasional maupun tingkat lokal pada periode 2016 - 2017. Dua teks yang menjadi wacana masyarakat bersumber di Jakarta, sementaara satu teks bersumber di Bali. Ketiga teks itu dipilih karena meluasnya pemberitaan liwat media utama, baik media lisan maupun medi tulis dan ketiganya ditangani oleh penegak hukum, kepolisian, kejaksaan dan pengadilan. Dua teks yang bersumber di Jakarta adalah (1) teks yang dihasilkan oleh Budi Tjahaja Purnama, alias Ahok, dengan topik teks "Surat Al Maidah Ayat 51" (tahun 2016), (2) teks yang dihasilkan oleh Eggy Sujana 


\section{STILISTIKA}

Journal of Indonesian Language and Literature

Vol.01, No.01: Oktober 2021, pp-82- 103.

yang dikenal dengan topik "Selain Islam Bertentangan dengan Pancasila" (tahun 2017), sementara (3) adalah teks yang dihasilkan oleh I Made Sudira yang dianggap menghina Gubernur Bali Mangku Pastika (2016).

Metode observasi sepenuhnya dilakukan dalam tahapan-tahapan pemilihan teks. Tahap pertama dilakukan pengamatan liwat berita-berita media arus utama: acara televisi dan pemberitaan surat kabar. Pilihan topik tertuju pada topik teks yang dianggap memicu pro dan kontra di masyarakat luas, kemudian tek-teks pemicu tersebut ditelusuri keberadaannya di media sosial terutama di media Youtube untuk teks lisan, dan di media Facebook untuk teks tulis. Metode observasi itu ditunjang dengan teknik transkripsi ortografis untuk teks lisan dan seknik salin-tempel (copy paste) untuk teks tulis. Setelah semua teks terkumpul, dilakukan idenfikasi dan klasifikasi berdasarkan kebutuhan analisis yang dikendalikan oleh permasalahan penelitian dan pendekatan Linguistik Forensik. Pendekatan Linguistik Forensik dalam peneltian ini ditunjang oleh teori mikrolinguistik terutama aspek morfologi dan sintaksis, sementara pendekatan makrolinguistik terutama aspek sosiopragmatik dan struktur wacana.

\section{HASIL DAN PEMBAHASAN}

Tiga teks yang dibahas di sini memiliki cirinya masing-masing yang semuanya dapat menimbulkan rasa permusuhan bagi kelompok masayarakat atau perorangan yang merasa direndahkan martabatnya. Dari segi 'konteks situasi' Halliday \& Hasan (1985) khususnya menyangkut motif partisipan sebagai penghasil teks, tidak berarti bahwa teks yang dihasilkan dimaksudkan untuk merendahkan martabat pihak lain, tetapi karena pilihan bentuk stilistika dari teks tersebut. Dalam pembahasan berikut dijelaskan bahwa Teks 1 dapat digolongkan sebagai teks yang bertopik administrasi pemerintahan, tetapi karena situasi politik menjelang pemilihan calon kepala daerah, 


\section{STILISTIKA}

Journal of Indonesian Language and Literature

Vol.01, No.01: Oktober 2021, pp-82- 103.

teks itu dipaksakan sebagai teks anti agama tertentu. Teks 2 sedikit berbeda dengan

Teks 1 terutama dilihat dari gagasan penghasil teks. Teks ini dapat digolongkan sebagai teks anti SARA terutama menyangkut soal perendahan agama-agama lain, selain agama kelompok tertentu. Teks 3 sebagai teks terakhir yang dibahas di sini berkaitan dengan individu dan individu, tetapi tiap-tiap individu itu merepresentasikan kelompok masyarakatnya sendiri-sendiri. Teks tersebut berlatar belakang perbedaan persepsi tentang pelestarian budaya. Berikut pembahasan ketiga teks tersebut.

\section{TEKS 1: 'SYARIAH ISLAM ATAU SEKULERISME'}

B.T.P alias Ak divonis bersalah oleh Majelis Hakim Pengadilan Negeri Jakarta Utara 9 Mei 2017 dalam kasus penodaan agama dan dihukum dua tahun penjara dan segera ditahan. Putusan dijatuhkan karena terdakwa dinyatakan bersalah melakukan penodaan agama karena menyebut Surat Al-Maidah Ayat $51^{3}$ dengan konotasi negatif saat berpidato di Kepulauan Seribu 27 September 2016. Ak dianggap 'tidak berhati-hati' dan menggunakan Surat Al-Maidah dengan 'konotasi negatif' yang bersifat merendahkan, melecehkan atau menghina simbol agama Islam. Oleh karena itu, Majelis Hakim menyatakan bahwa terdakwa terbukti melakukan tindak pidana melanggar Pasal 156a KUHP, yakni secara sengaja di muka umum mengeluarkan perasaan atau melakukan perbuatan permusuhan, penyalahgunaan, atau penodaan terhadap suatu agama. $^{4}$

Berikut bagian kutipan teks lisan yang diucapkan oleh Ak pada 27 September 2016: Data (1)

\footnotetext{
${ }^{3}$ Surat Al-Maidah Ayat 51 adalah bagian dari kitab suci Alqur'an.

${ }^{4}$ Liputan 6, 9 Mei 2017; Detik News, 9 Mei 2017.
} 


\section{STILISTIKA}

Journal of Indonesian Language and Literature

Vol.01, No.01: Oktober 2021, pp-82- 103.

"Jadi jangan percaya sama orang, kan bisa aja dalam hati kecil bapak ibu ga bisa pilih saya, ya, kan dibohongin pake Surat Al-Maidah 51 macem-macem itu. ${ }^{5}$ Itu hak bapak ibu."

Pidato Ak tersebut diunggah oleh B.Y di akun Facebook dengan mengedit beberapa bagiannya. B.Y kemudian diadili dan dijatuhkan hukum 1,5 tahun penjara pada 14/11/2017 oleh Pengadilan Negeri Bandung. Tindakannya itu dianggap melanggar Pasal 32 Ayat 1 UU ITE khususnya berkaitan dengan tindak pidana menghilangkan, mengubah dan menambah (sebagian dan/atau keseluruhan) dokumen elektronik milik orang lain. Sidang pengadilan terhadap B.Y dilakukan setelah Ak dijatuhi hukuman selama dua tahun penjara. ${ }^{6}$

Secara sintaksis, bagian dari teks itu adalah sebuah kalimat bawahan yang disisipkan di dalam kalimat luas. Jenisnya termasuk kalimat pasif karena intinya adalah kata kerja pasif dibohongin, sementara kata kerja $p a k e^{7}$ hanya disisipkan. Pertanyaan forensik -- yang sebagian besar belum pernah disinggung dalam sidang pengadilan meliputi tiga hal: (1) pelaku yang berbohong tidak disebutkan dalam kalimat pasif itu; (2) penggunaan kata 'pakai' mengimplikasikan bahwa Surat Al-Maidah Ayat 51 hanya dijadikan alat; ${ }^{8}$ dan (3) isi teks dari Surat Al-Maidah Ayat 51 itu hanya berlaku untuk kaum Muslim.

Pertama, dari segi struktur sintaksis, struktur kalimat pasif itu terdiri atas [Subjek di-VERBA (oleh PELAKU)]. Subjek dari dibohongin adalah anafora kosong yang koreferen dengan nomina sebelumnya, yakni, bapak-ibu, sementara Pelaku adalah

\footnotetext{
${ }^{5}$ Bagian klausa yang diucapkan oleh Ak ada pada menit ke 19.11 dari 47.14 menit puidatonya dengan warga Pulau Seribu. https://www.youtube.com/watch?v=Q8NGwzhjJG4

${ }^{6}$ Kompas.com, 14/11/2017.

${ }^{7}$ Menurut pendengaran penulis, Ak menggunakan bentuk takbaku dibohongin dan pake alih-alih bentuk baku dibohongi dan pakai.

${ }^{8}$ Butir (2) ini telah sebagian pernah disampaikan oleh Rahayu Surtiati ketika dia bertindak sebagai Saksi Ahli Bahasa dalam sidang pengadilan Ak.
} 


\section{STILISTIKA}

bentuk tersirat yang mengacu nomina orang generik (oleh) orang. Jika diucapkan secara lengkap kalimat tersebut seperti berikut ini.

Bapak-ibu dibohongin (oleh orang) pake Surat Al-Maidah Ayat 51.

Kedua, penggunaan kata 'pakai' mengimplikasikan bahwa kata kerja ini termasuk kata kerja transitif dengan Objek adalah frase nomina Surat Al-Maidah Ayat 51. Sebagai kata kerja sisipan, apabila keberadaannya dilesapkan, maka akan terdapat perubahan makna gramatikal dengan penapsiran Surat Al-Maidah Ayat 51 yang bohong. Alasan sintaksisnya adalah frase ini bertindak sebagai pelaku atau oblik langsung dari dibohongin. Akan tetapi, kalau kalimat itu tetap seperti apa adanya (tanpa ada penghilangan kata "pake"), maka yang berbohong itu adalah pelaku atau oblik generik yang tersirat (oleh orang); bukan Surat Al-Maidah Ayat 51.

Ketiga, pendekatan ko-teks harus diterapkan untuk mengaitkan bagian teks yang menjadi kasus hukum dengan teks yang berkaitan langsung tetapi tidak disebutkan secara tersurat dalam teks forensik tersebut. Pengaitan antara teks inti (teks yang menjadi objek kasus hukum) dan teks luar inti ini dilakukan agar didapat pemahaman yang lebih komprehensif. Ko-teks itu adalah isi dari Surat Al-Maidah Ayat 51 Alqur'an:

Data (2)

"Hai orang-orang beriman, janganlah kamu mengambil orang-orang Yahudi dan Nasrani menjadi pemimpin-pemimpin (mu); sebagian mereka adalah pemimpin yang bagi sebagian mereka yang lain. Barang siapa di antara kamu mengambil mereka menjadi pemimpin, maka sesungguhnya orang itu termasuk golongan mereka. Sesungguhnya Allah tidak memberi petunjuk kepada orang-orang yang zalim." (Departemen Agama RI dengan Surat Keputusan Menteri Agama Nomor 20 Tahun 1967. ALQUR'AN DAN TERJEMAHNYA, 2001:244):

Kitab suci dari suatu agama ditujukan sepenuhnya untuk penganut agama yang bersangkutan, bukan untuk penganut agama lain. Kitab suci Alqur'an adalah kitab suci 


\section{STILISTIKA}

agama Islam yang segala isinya wajib diikuti oleh umat Islam. Dalam konteks negara Islam atau negara berdasarkan Syariah Islam, aspek hukum didasarkan atas prinsipprinsip dasar Islam; umat non-muslim wajib menaatinya apabila mereka berada di bawah kendali sistem pemerintahan semacam itu. Sejumlah negara menerapkan sistem Syariah Islam yaitu negara yang berdasarkan hukum Islam, misalnya, Mesir, Afghanistan, Iran, Qatar, Arab Saudi, Yaman, Nigeria, dan Uni Emirat Arab. 9 Sebaliknya, Indonesia termasuk negara sekuler yang mengakui adanya keberagaman sesuai dengan ideologi Pancasila dan aspek hukum tertinggi adalah Undang-Undang Dasar 1945. Artinya, negara bersifat netral dalam urusan agama. ${ }^{10}$

Apabila konteks pragmatik 'Deiktik Orang' diterapkan, maka makna tersirat 'pemimpin' yang disebut dalam Surat Al-Maidah Ayat 51 harus diartikan sebagai pemimpin umat Islam dalam suatu negara yang berdasarkan hukum Islam. Sebaliknya, dalam sistem negara sekuler seperti Indonesia, istilah 'pemimpin' harus diartikan sebagai pemimpin pemerintahan untuk masyarakat yang berbeda-beda bukan hanya beda agama tetapi juga beda (suku) bangsa dan perbedaan lain. Kalau pemimpin sosialrelegius dari suatu organisasi kemasyarakatan agama tertentu, memang harus dari kalangan penganut agama itu. Contohnya, pemimpin organisasi kemasyarakatan Islam: Muhammadiyah, Nahdatul Ulama, dan Fron Pembela Islam harus dipimpin oleh seorang Muslim, tidak bisa dipimpin oleh seseorang dari agama lain. Sebaliknya, dalam konteks pemerintahan DKI Jakarta, seorang gubernur adalah pemimpin dari masyarakat Jakarta yang majemuk, bukan hanya pemimpin umat Islam. Hal ini sama kondisinya dengan negara-negara sekuler lain, contohnya, India, Amerika Serikat,

\footnotetext{
${ }_{9}^{9}$ Bandingkan Michiel Otto dalam CNN Internasional, 9/10/2014. Jan Michiel Otto dari University Law School, Leiden Belanda membedakan sistem hukum negara-negara Muslim menjadi: sistem syariah klasik, sistem sekuler, dan sistem campuran. Sistem campuran dari keduanya paling umum diterapkan di negara-negara mayoritas Muslim. Dalam hal ini, hukum keluarga mengikuti hukum Islam, sementara pengadilan mengikuti sistem sekuler.

${ }^{10}$ Di Indonesia hanya Provinsi Aceh menjadi satu-satunya provinsi yang menerapkan sistem Syariah Islam khususnya menyangkut hukum.
} 
Kanada, Filipina, Thailand, dan negara-negara lain yang banyak memiliki penduduk Muslim, tetapi pemimpin pemerintahannya tidak harus dari umat Muslim. Setakat ini, Indonesia sebagai negara sekuler berdasarkan Pancasila dan Undang-Undang Dasar 1945 tidak membatasi pemimpin pemerintahan harus beragama Islam, bisa dari agama lain.

Surat Al-Maidah Ayat 51 bisa saja dipakai oleh orang-orang tertentu untuk mewajibkan masyarakat berbeda agama dalam sistem negara sekuler. Jika tapsiran ini diterapkan, maka orang semacam itu adalah orang yang berbohong; BUKAN yang berbohong itu Surat Al-Maidah Ayat 51. Konteks pragmatiknya adalah DKI Jakarta sebagai acuan 'Deiktik Tempat' tidak berada di bawah kendali Syariah Islam tetapi di bawah kendali sistem sekuler. Oleh karena itu, masyarakat Indonesia di bawah ideologi Pancasila dan UUD $1945^{11}$ tidak wajib menerapkan Surat Al-Maidah Ayat 51 untuk kepemimpinan pemerintahan. Jadi, bagian teks yang menyatakan "...dibohongin pake Surat Al-Maidah Ayat 51..." tidak mengandung maksud penghinaan terhadp agama Islam karena Indonesia bukan negara Islam.

Sebagai perbandingan, berikut disajikan pandangan Saksi Ahli Bahasa yang diminta pendapatnya dalam siding pengadilan, baik saksi ahli yang meringankan maupun yang memberatkan terdakwa.

\section{Saksi Ahli Bahasa dari UI (Rahayu Surtiati):}

Hubungan antara kata kerja "pakai," "dibohongi," dan kata benda "Al-Maidah" mengimplikasikan bahwa yang berbohong bukan Alqur'an melainkan orang. Jadi, menurutnya, bagian kalimat Ak: “... dibohongi pakai Surat Al-Maidah...” tidak berarti

\footnotetext{
${ }_{11}$ Dasar ideologi negara adalah Pancasila, bukan Syariah Islam, yang tidak membedakan latar belakang agama, suku dan sebagainya. Dalam UUD 1945 (yang sudah diamendemen), Pasal 18, Ayat (4) disebutkan bahwa "Gubernur, Bupati, dan Walikota masing-masing sebagai kepala pemerintah daerah provinsi, kabupaten, dan kota dipilih secara demokratis." Demokratis berarti tidak membedakan agama, suku, dan sebagainya.
} 


\section{STILISTIKA}

Journal of Indonesian Language and Literature

Vol.01, No.01: Oktober 2021, pp-82- 103.

bahwa kebohongan ada dalam Surat Al-Maidah, tetapi itu hanya 'dijadikan alat untuk membohongi.' (https://www.bbc.com/indonesia/indonesia-39336200)

\section{Saksi Ahli Bahasa dari Universitas Mataram (Mahyuni):}

Menurut Prof Mahyuni, klausa yang diucapkan oleh Ak: “...dibohongi pakai Surat AlMaidah 51..." dapat dianggap sebagai 'ungkapan yang bermakna memojokkan dan negatif.' Alasannya adalah kata 'pakai' bersifat pasif, yang tidak mengubah makna kalimat. Jadi, disertakan atau tidak kata 'pakai' itu tidak berpengaruh. Karenanya, dalam kasus ini, tetap alat untuk membohongi itu adalah frase nomina Surat Al-Maidah. (https://merahputih.com/post/read/saksi-ahli-bahasa-frasa-dibohongi-pakai-al-maidah-51bernada-memojokan)

\section{TEKS 2: 'SELAIN ISLAM, BERTENTANGAN DENGAN PANCASILA'}

Pernyataan E.S -- yang menyatakan bahwa Hindu, Kristen dan Budha adalah tidak berketuhanan yang maha esa dan bertentangan dengan sila pertama Pancasila -telah menimbulkan banyak protes dan dia dilaporkan ke kepolisian. E.S dilaporkan oleh Dewan Pimpinan Nasional Perhimpunan Pemuda Hindu Indonesia (DPN Peradah) atas tuduhan penodaan agama yang diatur dalam Pasal 156a Undang-Undang KUHP. E.S juga dilaporkan oleh Aliansi Advokat Nasional ke Polda Metro Jaya 6 Oktober 2017 karena dianggap menyebarkan kebencian dan menista agama Kristen. Sementara itu, Pengurus Perwakilan Umat Buddha Indonesia (Walubi) hanya menyampaikan himbauan agar masyarakat berlomba-loma berbuat kebaikan, bekerja dan bersikap santun dalam menjalankan agamanya daripada mengurus ujaran kebencian yang disampaikan E.S. ${ }^{12}$ Berikut kutipan bagian teks lisan dari E.S:

${ }^{12}$ CNN Indonesia, 10 Oktober 2017; Kompas.com, 5 Oktober 2017; Tirto.id, 6 Oktober 2017. 


\section{STILISTIKA}

"Tidak ada ajaran selain Islam. Ingat, ya, digarisbawahi selain Islam yang sesuai dengan Pancasila. Selain Islam (.) bertentangan (.) karena Kristen (.) Trinitas, Hindu (.) Tri Murti, Budha, sepengetahuan saya tidak punya konsep Tuhan, ya, kecuali dengan proses Amitaba dan apa yang diajarkan oleh Sidarta Gautama. Jadi, ajaran-ajaran lain yang selain Islam (.) bertentangan dengan sila pertama,..."13

Pernyataan E.S tersebut di atas dikemukakan 2 Oktober 2017 di hadapan wartawan setelah sidang Pengadilan Konstitusi. ${ }^{14}$ Dalam sidang pengadilan itu, dia bertindak sebagai pengacara organisasi kemasyarakatan Hizbut Tahrir Indonesia (disingkat HTI) yang menggugat materi Peraturan Pengganti Undang-Undang (Perppu) Nomor 2 Tahun 2017 tentang Organisasi Kemasyarakatan. ${ }^{15}$ Berdasarkan Perppu itu pemerintah telah membubarkan Badan Hukum Ormas HTI $^{16}$ karena dianggap bertentangan dengan Pancasila dan UUD 1945.

Makna tersirat dari teks pernyataan E.S itu adalah 'hanya agama Islam yang mempercayai Tuhan Yang Maha Esa (monoteisme), sementara agama Hindhu, Kristen dan Budha menganut ajaran banyak Tuhan (politeisme). Oleh karena itu, ketiga agama tersebut harus dibubarkan karena bertentangan dengan Pancasila.' Untuk menguji pernyataan E.S tersebut, pendekatan ko-teks harus diterapkan dengan cara mengacu teks ajaran ketuhanan menurut agama Hindu, Kristen dan Budha.

\footnotetext{
${ }^{13}$ (.) berarti jeda singkat. Sumber teks: https://www.youtube.com/watch?v=Lyr5lh5uxBg

${ }^{14}$ Pernyataan ini juga disampaikan di dalam sidang Pengadilan Konstitusi oleh E.S.

15 Pasal 59 (Ayat 4c) Perppu Nomor 2 tahun 2017 berbunyi: “Ormas dilarang menganut, mengembangkan, serta menyebarkan ajaran atau paham yang bertentangan dengan Pancasila." Apabila Pasal 59 (Ayat 4) dilanggar, maka Status Terdaftar dan Status Badan Hukum Ormas bersangkutan dicabut, seperti diatur dalam Pasal 61 Ayat 3 Perppu Nomor 2 tahun 2017 yang berbunyi: “a. pencabutan surat keterangan terdaftar oleh Menteri; atau b. pencabutan status badan hukum oleh Menteri yang menyelenggarakan urusan pemerintahan di bidang hukum dan hak asasi manusia."

${ }_{16}$ Pasal 7 Rancangan Undang-Undang Dasar Negara (Khilafah) Islam menurut Hizbut Tahrir:

“Negara memberlakukan syariah Islam atas seluruh rakyat yang berkewarganegaraan (Khilafah) Islam, baik Muslim maupun non-Muslim...." (Hizbut Tahrir, 2012:338).
} 
Dalam pandangan agama Hindu, ${ }^{17}$ sebutan Sang Hyang Widi Wasa atau Brahman diartikan sama dengan 'Tuhan Yang Maha Esa.' Dalam konsep ajarannya, Sang Hyang Widhi atau Brahman mempunyai tiga nama berbeda, disebut Tri Murti 'tiga kekuatan Tuhan,' sesuai dengan fungsinya saat mengendalikan alam semesta. Ketika Tuhan menjalankan fungsinya sebagai pencipta, nama-Nya adalah Brahma; ketika Tuhan menjaga dan memelihara alam semesta, nama-Nya adalah Wisnu; dan ketika Tuhan melebur alam semesta yang sudah usang, nama-Nya adalah Siwa. (Pudja, 1982: 188; Hadiwijono, 1985: 127-128)

Konsep ajaran ketuhanan dalam Kristen juga menganut paham monoteisme. Dalam kaitan dengan konsep Trinitas dalam agama Kristen, E.S hanya melihatnya secara terpisah-pisah. Padahal, Trinitas merupakan Tritunggal 'satu Allah dalam tiga pribadi.' Allah yang memperanakkan, Yesus Kristus yang diperanakkan dan Roh Kudus yang dihembuskan - ketiga pribadi ini merupakan satu Allah. (Kirchberger, 2007: 211; Dister, 2004: 163-170; Wikipedea, 14/9/2018)

Dalam ajaran agama Budha, Ketuhanan Yang Maha Esa adalah sesuatu yang "tanpa Aku" (anatta), yang tidak dapat dipersonifikasikan (tanpa kepribadian), tidak dapat diuraikan seperti apa pun (sunyata) 'Yang Mutlak,' dan yang tidak berkondisi (asamkhata). Konsep "Yang Mutlak," "Yang Tidak Dilahirkan," “Yang Tidak Menjelma," dan "Yang Tidak Diciptakan" merupakan sifat Tuhan Yang Maha Esa (Hadiwijono, 1985: 77-78; Wikipedea, 14/9/2018).

Teks milik E.S mengabaikan teks terkait atau interteks yaitu teks tentang ajaran ketuhanan dari masing-masing agama tersebut di atas. E.S sebagai pemilik teks forensik itu mencoba merekayasa teks yang sebetulnya menyimpang dari teks ajaran yang berlaku dalam ketiga agama tersebut. E.S mengatakan bahwa ketiga agama selain Islam adalah politeisme, sementara hanya Islam yang monoteisme. Sebaliknya, teks ajaran

\footnotetext{
${ }_{17}$ Penulis dilahirkan sebagai seorang Hindu dan diajarkan sejak usia dini tentang konsep Tri Murti sebagai tiga kekuatan Tuhan Yang Maha Esa.
} 


\section{STILISTIKA}

Journal of Indonesian Language and Literature

Vol.01, No.01: Oktober 2021, pp-82- 103.

Kristen, Hindhu dan Budha mengatakan bahwa ajaran masing-masing agama tersebut menganut paham monoteisme.

Apakah implikatur dari teks yang direkayasa oleh E.S itu? Secara maksim direktif, implikaturnya adalah dia ingin meminta pemerintah Indonesia untuk tidak membubarkan HTI. Menurutnya, HTI justru tidak bertentangan dengan Ketuhanan Yang Maha Esa dan sudah bersesuaian dengan sila pertama Pancasila. Sebaliknya, E.S beranggapan bahwa Kristen, Hindhu dan Budha semestinya dibubarkan karena agamaagama ini menganut ajaran politeisme. Implikatur lanjutan dari teks direktif E.S adalah Pancasila termasuk ideologi yang bermasalah karena mengakui ajaran agama yang bertentangan dengan sila pertama.

\section{TEKS 3: 'KEPERDULIAN RITUAL ATAU KESELAMATAN WARGA'}

Teks yang ditulis di Facebook oleh M.S. alias A.J. - tentang keraguannya terhadap perhatian Gubernur Bali ${ }^{18}$ dalam melindungi budaya Bali -- menuai permasalahan hukum. M.S dilaporkan ke Polda Bali oleh Gubernur Bali 8 Juli 2016. Teks itu dianggap memiliki muatan penghinaan dan/atau pencemaran nama baik sebagaimana dimaksud dalam pasal 27 ayat (3) Jo pasal 45 ayat (1) UU.RI No.11/2008 tentang ITE dan/atau pasal 310 KUHP. Setelah dilakukan penyelidikan oleh pihak Polda Bali, kasus itu dihentikan karena tidak terdapat cukup bukti. Akan tetapi, pada 6 September 2016 M.S diperiksa kembali oleh Polda Bali dan pemeriksaan itu dicurigainya ada unsur intervensi dari Gubernur Bali. Pihak M.S pada 20 Oktober 2016 mengajukan gugatan Pra-peradilan terhadap Polda Bali atas pemeriksaan kembali tersebut. Berikut adalah bukti teks yang dimuat di Facebook 7 Juli 2016 (LBH Daerah Bali, 20 Oktober 2016):19

\footnotetext{
${ }_{18}$ Dia bernama M.M.P yang menjadi Gubernur Bali dua periode; periode I adalah 28 Agustus 2008 hinga 29 Agustus 2013; periode II adalah 29 Agustus 2013 hingga 29 Agustus 2018.

${ }_{19}$ Permohonan kepada Polda Bali agar mengawasi penyelidikan kasus UU ITE atas klien M.S. Permohonan ini diajukan oleh Lembaga Bantuan Hukum (LBH) Himpunan Advokat Muda Bersatu Dewan Pimpinan Daerah Bali.
} 
Data (4)

Pagi ini setelah acara megobedan atau acara mesangih, di rumah masing2 pengiring baik secara massal di Payadnyaan terkait upacara memukur di Puri Agung Jrokuta Denpasar, sore ini dilanjutkan dengan upacara ngangget Don Bingin. Sayang, acara tidak lagi dapat dilaksanakan di tempat biasa, seturut tradisi karena pohon beringin bernilai sakral tsb dipangkas daun dan rantingnya entah alsan apa? Ada yg berasumsi mungkin orang penting yg kini berumah-jabatan di sana tidak ingin terusik ketenangannya. Ohh begitu kah? Inikah cermin sikap ajeg Bali termutakhir? (LBH Daerah Bali, 20 Oktober 2016).

Hakim Pengadilan Negeri Denpasar 28 November 2016 mengabulkan gugatan M.S alias A.J terhadap Polda Bali. Pertimbangan hakim didasarkan atas keterangan dua saksi: saksi ahli bahasa dan saksi pengurus adat. Saksi ahli bahasa menyatakan bahwa teks di Facebook itu tidak mengandung makna penistaan atau pidana yang mengarah ke SARA. Teks itu hanya kegelisahan budaya yang diungkapkan dalam bentuk kritik.

Ada empat kalimat kunci dari teks yang dimuat di Facebook, yang menjadi keberatan pihak pelapor:

(4a) "Sayang, acara tidak lagi bisa dilaksanakan di tempat biasa seturut tradisi karena pohon beringin bernilai sakral tsb dipangkas habis daun dan rantingnya, entah alasan apa."

(4b) "Ada yang berasumsi, mungkin orang penting yg kini berumah-jabatan di sana tidak ingin terusik ketenangannya."

(4c) "Ohh begitu kah?"

(4d) "Inikah cermin sikap ajek Bali termutakhir."

Kalimat majemuk (4a dan $4 \mathrm{~b}$ ) merupakan pernyataan penulisnya yang dalam pendekatan pragmatik dapat dikategorikan sebagai 'maksim deklaratif.' Ada hubungan sebab-akibat antara kalimat majemuk (4a) dan kalimat majemuk (4b). Kalimat majemuk (4a) dapat diparafrasekan: 'penulis membuat pernyataan kepada masyarakat Bali bahwa salah satu kegiatan ritual pasca-kremasi masyarakat Denpasar Bali tidak dapat dilangsungkan karena pohon beringin sebagai pendukung upacara sudah dipangkas.' Kegagalan upacara ritual itu mengimplikasikan kekecewaan penulisnya yang 


\section{STILISTIKA}

Journal of Indonesian Language and Literature

Vol.01, No.01: Oktober 2021, pp-82- 103.

diungkapkan dengan adjektif penyesalan "sayang" di awal kalimat. Dalam kalimat majemuk (4b) penulis membuat pernyataan susulan yang mengungkapkan asumsi: "ada yang berasumsi" yang dapat diparafrasekan: 'penulis dan orang lain berasumsi bahwa alasan pohon beringin itu dipangkas agar kegiatan ritual tidak dapat berlangsung sehingga pejabat yang tinggal di sekitarnya tidak terganggu.' Kalimat majemuk (4b) ini diperkuat dengan kalimat tunggal (4c) berpredikat deiktik retorik "Ohh begitukah?" Kalimat ini dilanjutkan dengan kalimat tanya retorik (6d) yang merupakan simpulan penulisnya: "Inikah cermin sikap ajek Bali termutakhir." Implikaturnya adalah penulis itu meragukan keberpihakan Guberbnur Bali terhadap upaya pelestarian budaya Bali.

Dari konteks penulisnya, “.. pohon beringin bernilai sakral tsb dipangkas habis daun dan rantingnya..." berimplikasi bahwa meskipun daun beringin itu masih tersisa sedikit di pohon, pohon itu tetap tidak memenuhi syarat untuk proses upacara ritual. Sebaliknya, dari konteks Gubernur Bali, dapat ditapsirkan bahwa dalam pandangannya (sebagai orang yang tinggal di sekitar pohon beringin itu), pemangkasan pohon itu bukan dimaksudkan untuk menghalangi kegiatan ritual, tetapi semata-mata dimaksudkan untuk menjaga keamanan masyarakat yang lewat di bawahnya.

\section{SIMPULAN}

Makna tersirat teks bersifat ganda sehingga diperlukan analisis bukan hanya bentuk leksikal dan gramatikalnya, tetapi juga konteks verbal di sekitar teks dan konteks takverbal yang berada di luar teks. Konteks takverbal ini meliputi konteks partisipan, waktu, tempat yang secara pragmatik ketiganya berada dalam satu 'konteks deiktik:' deiktik orang, deiktik waktu dan deiktik tempat. Dari ketaksaan makna itu, harus diketahui aspek penekanan pesan yang ingin disampaikan oleh pemilik teks. Pemilik teks mempunyai misi agar teksnya dapat diperhatikan, dipercaya bahkan diikuti. Untuk mencapainya, pemilik teks dapat menyampaikan pesan tersiratnya 


\section{STILISTIKA}

Journal of Indonesian Language and Literature

Vol.01, No.01: Oktober 2021, pp-82- 103.

dalam bentuk pengungkapan perasaan, pernyataan, ajakan dan larangan. Pihak kedua yang disasar oleh teks akan dapat menerima atau menolaknya apabila perangkat tekstual yang bersifat lingual dikaitkan secara kon-tekstual dan ko-tekstual.

Selain hal di atas, peran konteks sosio-pragmatik juga sangat menentukan pesan sebuah teks terutama keterkaitannya dengan ranah-ranah kehidupan sosial, politik, agama dan budaya yang menunjang penentuan maksud di balik teks. Keberterimaan pesan sebuah teks bukan hanya ditentukaan oleh bukti-bukti linguistik dalam teks, tetapi juga tingkat keterkaitannya dengan konteks di luar teks dan ko-teks yaitu teks yang bertopik sama tetapi berada di luarnya.

\section{UCAPAN TERIMA KASIH}

Terima kasih kepada The Dean of Graduate School of Language and Culture Osaka University, Jepang, yang telah memberikan kesempatan penulis mengajar dan melakukan penelitian awal tentang Linguistik Forensik selama bertugas di sana (20172019). Terima kasih juga kepada Himpunan Peneliti Indonesia Seluruh Jepang, yang telah menerima penulis sebagai anggotanya sampai sekarang, dan diberikan kesempatan presentasi makalah di kota Nagoya, 17 - 18 November 2018.

\section{DAFTAR PUSTAKA}

Departemen Agama Republik Indonesia. 2001. Alqur'an dan Terjemahnya (Transliterasi Arab-Latin). Semarang: CV Asy Syfa'

Departemen Pendidikan Nasional. 2008. Kamus Besar Bahasa Indonesia Pusat Bahasa (Edisi Keempat). Jakarta: Gramedia Pustaka Utama.

Dister, Nico Syukur. 2004. Teologi Sistematika: Allah Penyelamat. Yogyakarta: Penerbit Kanisius

Foley, William A. 1997. Anthropological Linguistics: An Introduction. Oxford: Blackwell. Grundy, Peter. 2000. Doing Pragmatics. Second Edition. London: Hodder Arnold. Hadiwijono, H. 1985. Agama Hindu dan Budha. Jakarta: Gunung Mulia. 
Halliday, M.A.K and Hasan, R. 1985. Language, Context, and Text: aspekct of language in a social - semiotic perspective. Oxford: Oxford University Press.

Hizbut Tahrir. 2012. Daulah Islam (Edisi Mu'tamadah tahun 2002). Judul asli Ad-Daulah Al-Islamiyah. Diterjemahkan oleh Umar Faruq. Jakarta: Hizbut Tahrir Indonesia Press https://hizbut-tahrir.or.id

Kirchberger, G. 2007. Allah Menggugat: Sebuah Dogmatik Kristiani. Maumere: Penerbit Ledalero.

Mintowati, M.S. 2016. "Pencemaran Nama Baik: Kajian Linguistik Forensik." Dalam Jurnal Paramasastra Vol 3. 2. 2016; h. 27--37

Olsson, John and Luchjenbroers, June. 2014. Forensic Linguistics. London: Bloomsbury.

Pastika, I Wayan. 2018. "Kekeraasan Verbal dalam Teks Forensik Bahasa Indonesia." Makalah disajikan di Konferensi Internasional Masyarakat Linguistik Indonesia (KIMLI) di Manokwari, Papua, 13-16 Agustus 2018.

Pudja, G. 1982. Bhagawadgita (Pancama Weda). Jakarta: Maya Sari

Sadock, Jerrod. 2004. Speech Acts. In Laurence R. Horn and Gregory Ward. The Handbook of Pragmatics. Oxford. Blackwell.

Spencer-Oatey, Helen (Ed.). 2000. Culturally Speaking: Managing Rapport trough Talk across Cultures. London and New York: Continuum.

Saputro, Gozhali. 2019. "Studi Kasus Linguistik Forensik: Hoaks Rekaman Suara yang Diduga Gatot Nurmantyo. Dalam Jurnal Diksi Volume 27, Nomor 1, Maret 2019; h. $14-25$.

Van Dijk, Teún A. 2008. Discourse and Power. New York: Pilgrave Macmillan.

Wikipedea. 2018. Paparan bersumber dari Teks Perjanjian Baru - Matius 28: 19. Diakses $14 / 9 / 2018$

Wikipedea. 2018. Paparan bersumber dari Kitab Sutta Pitaka Udana VIII: 3. Diakses $14 / 9 / 2018$.

\section{PROFIL PENULIS}

I Wayan Pastika adalah profesor linguistik dan bahasa Indonesia di Fakultas Ilmu Budaya Universitas Udayana. Pendidikan Doktor bidang linguistik umum diselesaikan di Department of Linguistics, Faculty of Arts, The Australian National University di Australia tahun 2000. 1 April 2017 --1 April 2019 mengajar linguistik dan bahasa Indonesia di Osaka University, Jepang. Buku yang diterbitkannya dua tahun terakhir: Fonetik dan Fonologi: Tata Bunyi Bahasa (2019), Teks Media: Bahasa Politik Acara Televisi Indonesia (2020), BAHASA INDONESIA Buku Ajar untuk Mahasiswa (ko-editor, 
STILISTIKA

Journal of Indonesian Language and Literature

Vol.01, No.01: Oktober 2021, pp-82- 103.

2020). Tiga tahun terakhir ini Linguistik Forensik diberi perhatian dan beberapa makalah seminar tentang itu telah ditulisnya. 